\title{
Fine-scale site fidelity in California sea lions, Zalophus californianus, in the colony at Los Islotes, La Paz Bay, Mexico
}

\section{Fidelidad al sitio a escala fina en el lobo marino de California, Zalophus californianus, en la colonia Los Islotes, bahía de La Paz, México}

\author{
Andrea Rayas-Estrada ${ }^{1}$, Claudia Janetl Hernández-Camacho ${ }^{2 *}$ \\ 1 Departamento de Ciencias Marinas y Costeras, Universidad Autónoma de Baja California Sur, Carretera al \\ Sur, km 5.5, C.P. 23080, La Paz, Baja California Sur, México. \\ 2 Instituto Politécnico Nacional-Centro Interdisciplinario de Ciencias Marinas, Av. Instituto Politécnico \\ Nacional, s/n, colonia Playa Palo de Santa Rita, C.P. 23096, La Paz, Baja California Sur, México. \\ * Corresponding author. E-mail: cjhernandez78@gmail.com
}

\begin{abstract}
Fine-scale site fidelity in polygynous pinnipeds influences individual interactions, social stability, and gene flow; over time, demographic processes may be altered, and local extinction of some colonies may occur. The goal of this study was to evaluate fine-scale site fidelity as it relates to reproductive success of California sea lion, Zalophus californianus, adult females at 3 different reproductive sites in the Los Islotes rookery in La Paz Bay, Baja California Sur, Mexico. Reproductive history data for 5 cohorts of California sea lions marked as pups between 1980 and 1984 were used to estimate the individual fine-scale site fidelity index and the return rate. A Pearson correlation was used to evaluate whether there was a relationship between site fidelity and reproductive success (number of pups that a female had during the study period) during the 9-yr study period, and a chi-square test was used to compare reproductive success between sites. Adult female California sea lions showed high site fidelity to the colony, with the majority showing site fidelity values $>40 \%$; sites A and B had high return rates, whereas site $\mathrm{C}$ was the least preferred. There was no significant difference in the relationship between the fine-scale site fidelity index and reproductive success, or in reproductive success between sites. The high degree of fine-scale site fidelity apparently has not had negative effects on this colony, as evidenced by the significant increase in population size over the last 3 decades and the relatively high reproductive rates.
\end{abstract}

Key words: philopatry, reproductive success, inbreeding, Gulf of California.

RESUMEN. Dentro de los pinnípedos poligínicos, la fidelidad al sitio a escala fina influye en las interacciones individuales, la estabilidad social y el flujo genético; con el tiempo, puede afectar procesos demográficos e, incluso, llevar a la extinción local de algunas colonias. El objetivo de este trabajo fue estimar el grado de fidelidad al sitio a escala fina para hembras adultas de lobo marino de California, Zalophus californianus, en 3 áreas de reproducción y su relación con su éxito reproductivo en la colonia reproductiva Los Islotes, bahía de La Paz, Baja California Sur, México. Se estimó el índice de fidelidad al sitio a escala fina individual y la tasa de retorno a partir de la historia reproductiva de 5 cohortes de hembras marcadas desde crías entre 1980 y 1984. Se utilizó una correlación de Pearson para ver si existía una relación entre la fidelidad al sitio y el éxito reproductivo (número de crías que tuvo una hembra durante el periodo de estudio) de cada individuo durante el periodo de estudio de 9 años, y se comparó el éxito reproductivo entre sitios mediante una prueba de chi cuadrado. Las hembras adultas de lobo marino de California mostraron alta fidelidad a la colonia, la mayoría con valores de fidelidad al sitio por encima del 40\%; el sitio A y el sitio B mostraron la mayor tasa de retorno, mientras que el sitio $\mathrm{C}$ fue el de menor preferencia. No hubo diferencia significativa en la relación entre la fidelidad al sitio a escala fina y el éxito reproductivo, ni tampoco en el éxito reproductivo entre sitios. La elevada fidelidad al sitio a escala fina aparentemente no ha tenido efectos negativos en esta colonia, como lo indica el aumento significativo de la población en las últimas 3 décadas y sus tasas reproductivas relativamente altas.

Palabras clave: filopatría, éxito reproductivo, endogamia, golfo de California.

\section{INTRODUCTION}

Pinnipeds are marine mammals that live partly in the ocean (e.g., for feeding, resting, migrating) and partly on land (e.g., for maternal care, resting, and mating) (King 1983). In general, polygynous pinnipeds (ottarids and some phocids) are highly philopatric (tendency to return to the natal site) (Pomeroy et al. 2000, Chilvers and Wilkinson 2008). Females continuously return to the colonies where they gave birth to

\section{INTRODUCCIÓN}

Los pinnípedos son mamíferos marinos que realizan algunas actividades en agua (e.g., alimentación, descanso y migración) y otras en tierra (e.g., cuidado materno, descanso y apareamiento) (King 1983). En general, los pinnípedos poligínicos (otáridos y algunos fócidos) son altamente filopátricos (regreso a la zona natal) (Pomeroy et al. 2000, Chilvers y Wilkinson 2008). Las hembras regresan continuamente a 
nurse their offspring during the lactation period (Peterson and Bartholomew 1967, Melin et al. 2000, Wolf and Trillmich 2007, Hoffman and Forcada 2012). Conversely, most adult and subadult males migrate and abandon the colonies at the end of the breeding season and return before the next one begins (Peterson and Bartholomew 1967, Elorriaga-Verplancken et al. 2018).

Philopatric behavior can influence not only social structure but also evolutionary processes and gene flow patterns. This behavior promotes inbreeding, which reduces genetic variability in populations given the presence of identical alleles. Reduced genetic variability increases the presence of homozygous individuals, which is counterproductive for life history traits such as growth, reproduction, survival, and the potential for evolution, adaption, and speciation, up to the extent of driving some populations to extinction (Greenwood 1980, Matthiopoulos et al. 2005, Campbell et al. 2007, Chilvers and Wilkinson 2008, Serna-Lagunes and Díaz-Rivera 2011). Nonetheless, philopatry allows individuals to adapt to the conditions in their local environment, thus balancing intraspecific competition for resources (GonzálezForero 1998, Schramm et al. 2009).

In addition to being philopatric, some pinnipeds exhibit intracolonial site fidelity or fine-scale site fidelity, where an individual prefers a site or specific territory within a colony throughout its lifetime (Lunn and Boyd 1991, Cassini 2000, Pomeroy et al. 2000, Wolf et al. 2005, Cameron et al. 2007, Wolf and Trillmich 2007). When fine-scale site fidelity is persistent, aggregations of related individuals are formed, which increase access to limited resources or to the best nursing sites, decrease the frequency of male agonistic encounters and harassment, and promote altruistic behavior; this creates social stability within the colony and increases reproductive success in gregarious species (Cassini 2000, Pomeroy et al. 2000, Cameron et al. 2007, Wolf and Trillmich 2007).

Studies on fine-scale site fidelity in pinniped colonies are scarce because these studies require long-term databases of the geographic locations of individuals in a colony. For this, animals must be permanently branded at birth and tracked throughout their lifetime. Some of these studies have found correlations of age, sex, and reproductive success with fine-scale site fidelity. In the Galápagos sea lion, Zalophus wollebaeki, males were found to use sites that were not frequently used by females (Wolf et al. 2005, Wolf and Trillmich 2007). Moreover, females with pups used different sites from females without pups or with older pups. In the Antarctic fur seal, Arctocephalus gazella, reproductive success was reported to be a better predictor of the ability of females to occupy preferred sites in a colony (Hoffman and Forcada 2012). Likewise, studies on Weddell seals, Leptonychotes weddellii, showed that females having more pups within a certain period of time were more likely to visit the same sites than females having less pups (Cameron et al. 2007).

California sea lion colonies in Mexico are in a critical state given the alarming declines in past decades (Szteren las colonias donde dieron a luz a amamantar a sus crías a lo largo del periodo de lactancia (Peterson y Bartholomew 1967, Melin et al. 2000, Wolf y Trillmich 2007, Hoffman y Forcada 2012). En contraste, la mayoría de los machos adultos y subadultos migran y abandonan las colonias al final de la temporada de reproducción y regresan antes de que comience la siguiente temporada (Peterson y Bartholomew 1967, Elorriaga-Verplancken et al. 2018).

El comportamiento filopátrico no sólo influye en la estructura social, sino también en los procesos evolutivos y los patrones de flujo de genes. Este comportamiento favorece los apareamientos endogámicos, lo cual reduce la variabilidad genética en las poblaciones debido a la presencia de alelos idénticos. Esta reducción en la variabilidad genética favorece la presencia de individuos homocigotos, que resulta contraproducente para las características de historia de vida como el crecimiento, la reproducción, la supervivencia y el potencial evolutivo, adaptativo y de especiación, a tal grado de llevar a la extinción a algunas poblaciones (Greenwood 1980, Matthiopoulos et al. 2005, Campbell et al. 2007, Chilvers y Wilkinson 2008, Serna-Lagunes y Díaz-Rivera 2011). Sin embargo, a través de la filopatría, los individuos se adaptan a las condiciones del ambiente local y, por lo tanto, se produce un equilibrio en la competencia intraespecífica por los recursos (González-Forero 1998, Schramm et al. 2009).

Además de ser filopátricos, algunos pinnípedos exhiben fidelidad al sitio intracolonial o fidelidad al sitio a escala fina, donde los individuos prefieren un sitio o territorio específico dentro de una colonia a lo largo de su vida (Lunn y Boyd 1991, Cassini 2000, Pomeroy et al. 2000, Wolf et al. 2005, Cameron et al. 2007, Wolf y Trillmich 2007). Si la fidelidad al sitio a escala fina llega a ser persistente, se producen agregaciones de individuos relacionados que favorecen el acceso a los recursos limitados o mejores sitios de crianza, disminuye la frecuencia de encuentros agonísticos y el acoso por parte de los machos y se favorece el comportamiento altruista; por lo tanto, se crea una estabilidad social dentro de la colonia y aumenta el éxito reproductivo en especies gregarias (Cassini 2000, Pomeroy et al. 2000, Cameron et al. 2007, Wolf y Trillmich 2007).

Los estudios de fidelidad al sitio a escala fina en pinnípedos son escasos debido a que es necesario contar con una base de datos de muchos años de la ubicación de los individuos dentro de una colonia. Esto requiere marcar de forma permanente a los animales desde el nacimiento y seguirlos a lo largo de toda la vida. Algunos de estos estudios han encontrado una relación de la edad, el sexo y el éxito reproductivo con la fidelidad al sitio a escala fina. En el lobo marino de Galápagos, Zalophus wollebaeki, se encontró que los machos utilizaron sitios menos frecuentados por las hembras (Wolf et al. 2005, Wolf y Trillmich 2007). Además, las hembras con cría usaron sitios distintos a los que ocuparon las hembras sin cría o con cría de mayor edad. Para el lobo marino antártico, Arctocephalus gazella, se reportó que el éxito reproductivo puede ser un mejor predictor de la capacidad de las 
Rayas-Estrada and Hernández-Camacho: Fine-scale site fidelity in California sea lions

et al. 2006). Los Islotes is one of the few colonies where California sea lion populations have increased, and it is thus a very important site for the conservation of this species. Understanding life history traits, such as fine-scale site fidelity, can help us elucidate the social and genetic structure of California sea lions and infer the recolonization rate in rookeries (Greenwood 1980, Matthiopoulos et al. 2005).

In the present study we estimated the degree of finescale site fidelity in female California sea lions (Zalophus californianus) and its relationship with reproductive success (number of pups a female had during the study period) at Los Islotes rookery, La Paz Bay, Mexico.

\section{MATERIALS AND METHODS}

\section{Study area}

Los Islotes is a small rocky island located on the northeastern boundary of La Paz Bay, Gulf of California (Fig. 1), and it is formed by 2 volcanogenic sedimentary rock islets that together extend out to a total surface area of $0.046 \mathrm{~km}^{2}$ (Labrada-Martagón et al. 2005, Young and Gerber 2008). It is inhabited by a breeding colony of $\sim 600$ sea lions.

The rookery is divided into 3 main breeding sites: A, B, and C. The first 2 host $32 \% \pm 4$ and $15 \% \pm 3$ of the total population size, respectively. Surface areas for sites A, B, and C are $802 \mathrm{~m}^{2}, 122 \mathrm{~m}^{2}$, and $254 \mathrm{~m}^{2}$ (Young and Gerber 2008), and current sea lion densities are 0.20 ind $\cdot \mathrm{m}^{-2}, 0.48$ ind $\cdot \mathrm{m}^{-2}$, and 0.65 ind $\cdot \mathrm{m}^{-2}$, respectively. Site $\mathrm{C}$ was a "bachelor zone" occupied by non-territorial males, but territorial males began to use it approximately 10 years ago. At present, site $\mathrm{C}$ is the breeding site with the most individuals in the colony $(33 \% \pm 2)$ (Hernández-Camacho 2001, Labrada-Martagón et al. 2005); the rest of the population $(\sim 20 \%)$ is distributed in the intermediate zones of the island.

\section{Branding and resighting of individuals}

The analysis was done using the presence-absence database pertaining to 5 generations (1980-1984) of California sea lion females that were hot-iron branded as pups at Los Islotes (Hernández-Camacho et al. 2008a, b). Pups were captured and branded in the first week of July at sites A and B; site $\mathrm{C}$ was a bachelor zone and there were no pups there. When branding was carried out, the study sites in the colony had not been defined yet. Pups were manually held and branded by 4 people. Markings were composed of 1,2 , or 3 digits and were applied on the dorsal side; digits measured $8 \mathrm{~cm}$ in length and were placed $2.5 \mathrm{~cm}$ apart from each other. Animals were captured and branded with the research and collection permits granted by the General Directorate for Wildlife (Dirección General de Vida Silvestre, Mexico). Branding had no negative effects on pup survival, nor did it cause any infection or scarring issue that could compromise legibility (Aurioles and Sinsel 1988, Hernández-Camacho 2001). The hembras a ocupar sitios preferidos dentro de las colonias (Hoffman y Forcada 2012). Así mismo, en la foca de Weddell, Leptonychotes weddellii, se observó que las hembras que tienen más crías en un periodo tienen más probabilidad de visitar los mismos sitios que las hembras con menos crías (Cameron et al. 2007).

Las colonias de lobo marino de California en México se encuentran en estado crítico, dada su alarmante disminución en las últimas décadas (Szteren et al. 2006). Los Islotes es una de las pocas colonias donde la población de lobo marino de California ha aumentado, por lo que es un sitio de suma importancia para la conservación de la especie. Conocer aspectos de su historia de vida, como la fidelidad al sitio a escala fina, nos permite elucidar la estructura social y genética del lobo marino de California, así como inferir la tasa de recolonización de colonias reproductivas (Greenwood 1980, Matthiopoulos et al. 2005).

En el presente estudio se estimó el grado de fidelidad al sitio a escala fina para hembras de lobo marino de California (Zalophus californianus) y su relación con el éxito reproductivo (número de crías que tuvo una hembra durante el periodo de estudio) en la colonia Los Islotes, bahía de La Paz, México.

\section{MATERIALES Y MÉTOdOS}

\section{Área de estudio}

Los Islotes es una pequeña isla rocosa ubicada en el límite nororiental de la bahía de La Paz, golfo de California (Fig. 1), y está compuesta por 2 islotes de rocas volcano-sedimentarias que conforman una extensión superficial de $0.046 \mathrm{~km}^{2}$ (Labrada-Martagón et al. 2005, Young y Gerber 2008). Es habitada por una colonia reproductora de aproximadamente 600 lobos marinos.

La colonia se divide en 3 sitios de reproducción principales: A, B y C. Los dos primeros albergan $32 \% \pm 4$ y $15 \% \pm 3$ de la población total, respectivamente. El área de cada sitio es de $802 \mathrm{~m}^{2}, 122 \mathrm{~m}^{2}$ y $254 \mathrm{~m}^{2}$ (Young y Gerber 2008), y la densidad de lobo marino actual es de $0.20 \mathrm{ind} \cdot \mathrm{m}^{-2}, 0.48 \mathrm{ind} \cdot \mathrm{m}^{-2}$ y $0.65 \mathrm{ind} \cdot \mathrm{m}^{-2}$, respectivamente. La zona $\mathrm{C}$ era una "zona de solteros" ocupada por machos no territoriales; sin embargo, hace aproximadamente 10 años, comenzó a ser ocupada por machos territoriales. Es, actualmente, la zona de reproducción donde se concentra la mayoría de los individuos de la colonia $(33 \% \pm 2)$ (Hernández-Camacho 2001, Labrada-Martagón et al. 2005); el resto de la población ( $\sim 20 \%$ ) se distribuye en las áreas intermedias de la isla.

\section{Marcaje y reavistamiento de individuos}

El análisis se realizó a partir de una base de datos de la presencia o ausencia de 5 generaciones (1980-1984) de hembras de lobo marino de California marcadas con hierro caliente desde crías en Los Islotes (Hernández-Camacho et al. 2008a, b). Las crías se capturaron y marcaron en la primera 
hot-iron branding method has been used to identify California sea lions at San Miguel Island, California, since 1987, with no reported negative effects on pup survival or reproductive success (DeLong et al. 2017).

In total 94 females were branded accross the study period. Males were also branded $(n=96$, Table 1$)$, but resightings were insufficient for estimating the fine-scale site fidelity index. Of the 96 branded males, only 29 were resighted in 1994, when we had started recording the reproductive status and location of the animals in the colony. During the 9-year study (1994-2003), 16 males from all cohorts were observed in only one breeding season, 10 males from all cohorts were observed in 2 to 3 seasons, and only 3 males from the 1983 and 1984 cohorts were observed in 6 to 9 consecutive seasons.

After branding, the colony was systematically visited for 9 to 15 days during the breeding seasons from 1994 to 2003 . The site (A, B, or $\mathrm{C})$ where each individual was observed and the reproductive status (female with pup or no pup) of adults were recorded in every visit (Hernández-Camacho et al. 2008a, b). Sightings were made from a vessel sailing around the island and from land at the main study sites using binoculars. The number of resighted females decreased over time because individuals died with the passing years (Hernández-Camacho et al. 2008a). In the first year of the study (1994), 38 females were recorded, and in the last (2003) only 17 females were recorded. semana de julio de cada año en los sitios A y B; el sitio C era una zona de solteros, por lo que no había crías. Cuando el marcado se llevó a cabo, no estaban definidos los sitios de estudio dentro de la colonia. Cada cría fue sostenida manualmente para aplicar la marca entre 4 personas. Las marcas fueron compuestas por 1, 2 o 3 dígitos y colocadas en la parte dorsal; los dígitos tenían una longitud de $8 \mathrm{~cm}$ y se colocaron a $2.5 \mathrm{~cm}$ uno de otro. La captura y el marcaje de animales se realizaron bajo el amparo del respectivo permiso de investigación y recolecta otorgado por la Dirección General de Vida Silvestre (México). El marcado no tuvo efecto negativo en la supervivencia de las crías ni tampoco causó infecciones o problemas de cicatrización que comprometieran la legibilidad (Aurioles y Sinsel 1988, Hernández-Camacho 2001). El marcado con hierro caliente ha sido utilizado para identificar lobos marinos de California de la isla San Miguel, California, desde 1987, sin que se haya reportado algún efecto negativo en su supervivencia o éxito reproductivo (DeLong et al. 2017).

En total, se marcaron 94 hembras en todo el periodo de estudio. También se marcaron machos $(n=96$, Tabla 1), pero no hubieron suficientes reavistamientos para estimar el índice de fidelidad al sitio a escala fina. De los 96 machos marcados, únicamente se re-avistaron 29 machos en 1994, cuando empezamos a registrar el estado reproductivo y la ubicación de los animales dentro de la colonia. En los 9 años (1994-2003) de

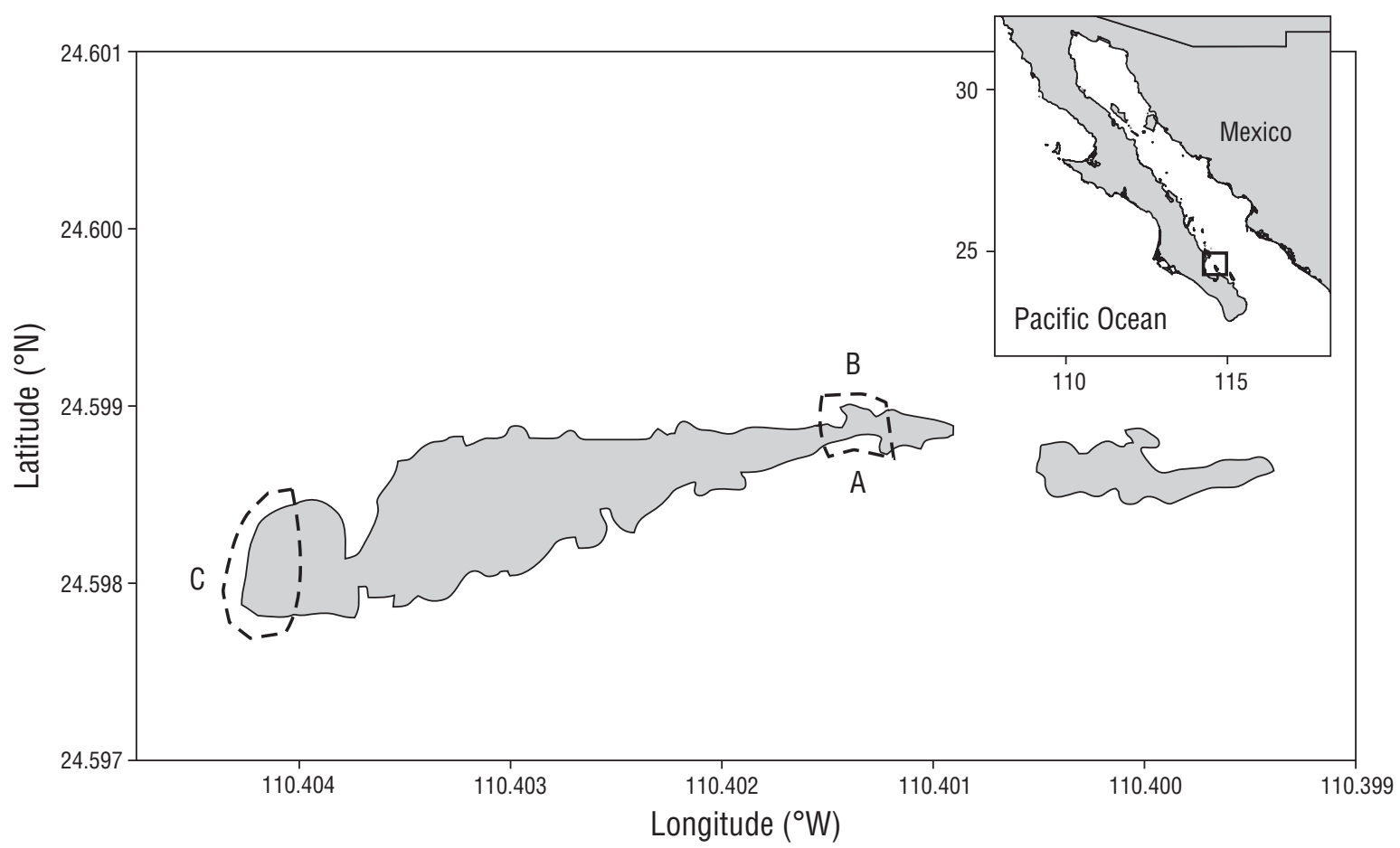

Figure 1. Los Islotes rookery, Gulf of California, Mexico. Sites where most individuals gather during the mating season are indicated as A, $\mathrm{B}$, and $\mathrm{C}$.

Figura 1. Lobera Los Islotes, golfo de California, México. Los sitios donde se congrega la mayoría de los individuos durante la temporada de reproducción se indican como A, B y C. 
Table 1. Number of male and female pups that were branded during the mating seasons from 1980 to 1984 at the Los Islotes rookery, Gulf of California. The total number of pups born each year was estimated from counts performed on board and on land during the second week of July, when most births had occurred (García-Aguilar and Aurioles-Gamboa 2003).

Tabla 1. Número de crías macho y hembra marcadas durante las temporadas de reproducción de 1980 a 1984 en la lobera Los Islotes, golfo de California. El número total de crías nacidas cada año se estimó a partir de conteos desde embarcación y desde tierra durante la segunda semana de julio, cuando la mayoría de los nacimientos habían ocurrido (García-Aguilar y Aurioles-Gamboa 2003).

\begin{tabular}{lccc}
\hline Cohort & Males & Females & $\begin{array}{c}\text { Branded relative to } \\
\text { pups born (\%) }\end{array}$ \\
\hline 1980 & 17 & 8 & 65.8 \\
1981 & 18 & 17 & 76.0 \\
1982 & 19 & 18 & 68.5 \\
1983 & 24 & 26 & 100.0 \\
1984 & 18 & 25 & 87.8 \\
Total & 96 & 94 & 79.6 \\
\hline
\end{tabular}

\section{Fine-scale site fidelity index}

To measure fine-scale site fidelity, we developed the following index using data of females with more than 4 sightings in every breeding season to increase certainty $(n=38$ females):

$$
F I_{i}=\frac{P_{i}}{T S P}
$$

where $F I_{i}$ is the fine-scale site fidelity index for individual $i$, $P_{i}$ is the probability of sighting individual $i$ at the preferred site $\left(P_{i}=S P / A\right), S P$ is the number of times individual $i$ was sighted at the preferred site, $A$ is the total number of times individual $i$ was sighted in a season, and TSP is the total number of sites preferred by individual $i$.

The return rate was estimated to determine the degree of fidelity to sites A, B, and C in one year with respect to the previous year and to sites $A$ and $B$ in each year with respect to the first year of sightings (1994) since data for site C was insufficient. In addition, we could not determine the differences in the return rates between sites because of the low number of samples obtained for sites $\mathrm{A}$ and $\mathrm{B}$. The return rate $(R T)$ was estimated using the method described by Acevedo et al. (2006):

$$
R T=\left(\frac{N_{r x}}{N_{t x}}\right) \times 100
$$

where $N_{r x}$ is the total number of California sea lion females recaptured in year $x$, and $N_{t x}$ is the total number of branded California sea lion females sighted in year $x$.

A Pearson correlation was used to explore whether there was a correlation between the fine-scale site fidelity index and estudio, 16 machos de todas las cohortes fueron vistos solo en una temporada de reproducción, 10 machos de todas las cohortes fueron vistos entre 2 y 3 temporadas y solo 3 machos de las cohortes 1983 y 1984 fueron vistos entre 6 y 9 temporadas consecutivas.

Después del marcaje, se realizaron visitas sistemáticas a la colonia de entre 9 y 15 días durante las temporadas de reproducción de 1994 a 2003. Durante cada visita, se registró el sitio (A, B o C) donde era observado cada individuo y su estado reproductivo (hembras con cría o sin cría) cuando fueron adultos (Hernández-Camacho et al. 2008a, b). Las observaciones se realizaron desde una embarcación alrededor de la isla y desde tierra en las zonas principales de estudio usando binoculares. El número de hembras re-avistadas disminuyó con el tiempo debido a que los individuos murieron con los años (Hernández-Camacho et al. 2008a). En el primer año (1994) se registraron 38 hembras y en el último (2003), solo 17 hembras.

\section{Índice de fidelidad al sitio a escala fina}

Para medir la fidelidad al sitio a escala fina, se desarrolló el siguiente índice usando los datos de las hembras con más de 4 avistamientos en cada temporada de reproducción para aumentar la confiabilidad ( $n=38$ hembras):

$$
I F_{i}=\frac{P_{i}}{T S P}
$$

donde $I F_{i}$ es el índice de fidelidad al sitio a escala fina del individuo $i, P_{i}$ es la probabilidad de avistar al individuo $i$ en el sitio preferido $\left(P_{i}=S P / A\right), S P$ es el número de ocasiones en que el individuo $i$ fue encontrado en el sitio preferido, $A$ es el número total de ocasiones en que se observó al individuo $i$ durante una temporada y TSP es el número total de sitios preferidos por el individuo $i$.

Se estimó la tasa de retorno para determinar el grado de fidelidad al sitio que existía en los sitios $\mathrm{A}, \mathrm{B}$ y $\mathrm{C}$ en un año con respecto al anterior y en cada año con respecto al primer año de avistamiento (1994) excepto para el sitio C porque no teníamos datos suficientes. Además, no fue posible determinar si hubo diferencia en la tasa de retorno entre sitios, debido al pequeño número de muestra obtenido para los sitios A y B. La tasa de retorno (TR) se estimó mediante el método de Acevedo et al. (2006):

$$
T R=\left(\frac{N_{r x}}{N_{t x}}\right) \times 100
$$

donde $N_{r x}$ es el total de hembras de lobo marino de California recapturadas en el año $x$ y $N_{t x}$ es el total de hembras marcadas de lobo marino de California avistadas en el año $x$.

Se exploró si existía una relación entre el índice de fidelidad al sitio a escala fina y el éxito reproductivo de cada individuo durante todo el periodo de estudio mediante una correlación de Pearson. Para realizar la correlación, fue necesario calcular un valor de éxito reproductivo dividiendo el 
the reproductive success of each individual during the study period. For the correlation, the reproductive success value was calculated by dividing the number of pups each female had (one pup per season) by the number of sampling years $(n=9)$. A chi-squared $\left(\chi^{2}\right)$ test was used to determine if there were differences between the percentage of branded females that had pups and were always sighted at site A and the percentage of females that had pups and were always sighted at site B. Only the last 2 generations of females were considered because these were the only generations for which there was sufficient data. Analyses were done in R (R Core Team 2018); differences were considered significant when $P<0.05$. Given our small sample size, we were unable to associate age and sex with the degree of site fidelity.

\section{Results}

Most California sea lion females showed site fidelity indices $>40 \%$. In all, $34 \%$ of individuals showed indices $>80 \%$ (Fig. 2). Yearly return rates with respect to the previous sighting year were highest for sites $\mathrm{A}$ and $\mathrm{B}$; however, site $\mathrm{A}$ was used the most across all seasons. The decrease in the return rate for site $\mathrm{C}$ was attributed to the lower number of females present at this site compared to the other sites, so when an individual from that site was not resighted, the return rate decreased notably. For this analysis, each interval on the $x$-axis in Figure 3a shows the number of recaptured animals from the previous year; for example, the first interval shows that more than $60 \%$ of the animals identified at site $\mathrm{A}$ in 1994 were recaptured in 1996. The return rate with respect to the first year of analysis (1994) did not show a clear pattern, though individuals did show preference for site A (Fig. 3b).

No significant correlation was found between reproductive success and the site fidelity index $\left(P>0.05, \rho_{x y}=-0.2852\right)$ (Fig. 4a). The trend, however, was negative, meaning that when reproductive success increased, the fine-scale site fidelity index decreased. No significant differences were observed in the percentage of females with pups between sites A and $B\left(\chi^{2}=8.66\right)$ (Fig. $\left.4 b\right)$; that is, no site was preferred for nursing.

\section{Discussion}

Fine-scale site fidelity is an important trait that determines the home range of species and the social structure within colonies (Amos and Harwood 1998, Chesser 1998, Pomeroy et al. 2000). California sea lion females at Los Islotes showed a high degree of fine-scale site fidelity, as has been reported for Antarctic fur seals, Galápagos sea lions, and Weddell seals (Cameron et al. 2007, Wolf and Trillmich 2007, Hoffman and Forcada 2012).

In some species, fine-scale site fidelity changes depending on the age category, reproductive success, and population density in the colonies (Cameron et al. 2007, Wolf and Trillmich 2007). In general, adults show higher site fidelity número de crías que tuvo una hembra (una cría por temporada) entre el número de años de muestreo $(n=9)$. Para determinar si hubo diferencias entre el porcentaje de hembras marcadas que tuvieron cría que siempre se vieron en el sitio A y el porcentaje de hembras marcadas que tuvieron cría que siempre se vieron en el sitio B, se realizó una prueba de chi cuadrado $\left(\chi^{2}\right)$. Sólo se tomaron en cuenta a las hembras de las últimas 2 generaciones debido a que eran las únicas para las que se tenían datos suficientes. Los análisis se realizaron en R (R Core Team 2018); las diferencias significativas fueron consideradas a un nivel de $P<0.05$. Debido a que nuestro tamaño de muestra fue pequeño, no fue posible analizar la relación entre la edad y el sexo con el grado de fidelidad al sitio.

\section{Resultados}

La mayoría de las hembras de lobo marino de California presentaron índices de fidelidad al sitio $>40 \%$. El $34 \%$ de los individuos alcanzaron índices $>80 \%$ (Fig. 2). Los sitios A y B fueron las zonas con mayor tasa de retorno en cada año con respecto al año previo de avistamiento; sin embargo, el sitio A fue el más utilizado por las hembras a lo largo de todas las temporadas. La disminución en la tasa de retorno en el sitio $\mathrm{C}$ se debió a que el número de hembras fue más bajo ahí que en los otros sitios, por lo que cuando no se re-avistó a alguno de los animales de ese sitio, la tasa de retorno disminuyó notablemente. En este análisis, cada intervalo del eje $x$ en la Figura 3a muestra el número de animales recapturados del año previo; por ejemplo, en el primer intervalo, más del $60 \%$ de los animales identificados en el sitio A en 1994 fueron recapturados en 1996. La tasa de retorno con respecto al primer año de análisis (1994) no mostró un patrón claro, aunque los individuos prefirieron el sitio A (Fig. 3b).

No se encontró una correlación significativa entre el éxito reproductivo y el índice de fidelidad al sitio $(P>0.05$, $\rho_{x y}=-0.2852$ ) (Fig. 4a). Sin embargo, la tendencia fue negativa, es decir, que a mayor éxito reproductivo, menor índice de fidelidad al sitio a escala fina. No se encontró diferencia significativa en el porcentaje de hembras que tuvieron cría entre el sitio A y el sitio B $\left(\chi^{2}=8.66\right)$ (Fig. $\left.4 b\right)$, es decir, que no hubo un sitio preferido para la crianza.

\section{Discusión}

La fidelidad al sitio a escala fina es una característica importante que determina el área de hogar de las especies y la estructura social dentro de las colonias (Amos y Harwood 1998, Chesser 1998, Pomeroy et al. 2000). Las hembras de lobo marino de California de Los Islotes presentaron un alto grado de fidelidad al sitio a escala fina, tal como se ha reportado para el lobo fino Antártico, el lobo marino de Galápagos y la foca de Weddell (Cameron et al. 2007, Wolf y Trillmich 2007, Hoffman y Forcada 2012). 
than juveniles because juveniles explore alternative sites in their natal colony or in other colonies when they are excluded from the breeding sites (Baker et al. 1995). We were unable analyze site fidelity by age categories for the California sea lion because we had more data of females in younger age classes, as some females from the first cohorts had already died by the time we started the site-fidelity study in 1994.

The degree of fine-scale site fidelity is positively correlated with female reproductive success or the number of pups in a territory in species like the Antarctic fur seal (Lunn and Boyd 1991), the Galápagos sea lion (Wolf and Trillmich 2007), and the Weddell seal (Cameron et al. 2007). However, in the present study we did not find a positive correlation between reproductive success and fine-scale site fidelity, nor did we identify a preferred site for nursing; we believe the opposing trends in the percentage of females with pups between years and sites are due to chance. If one of the sites were the more suitable for nursing, then the percentage of females with pups at that site would have had to have been higher throughout the study period.

Regarding the density of animals in colonies, Matthiopoulos et al. (2005) indicated that populations that slowly decrease in size or have low densities tend to show higher site fidelity and philopatry than populations with fast growth rates or high densities. In the present study, we did not have data on animal density for every site and every year, except for 2000, 2002, and 2003 (Young and Gerber 2008), and we were thus unable to analyze the correlation between population density and the fine-scale site fidelity index for the whole study period. Nonetheless, analysis of those 3 years showed that site B had the highest density $\left(0.20\right.$ ind $\left.\cdot \mathrm{m}^{-2}\right)$, followed by site $\mathrm{C}\left(0.09 \mathrm{ind} \cdot \mathrm{m}^{-2}\right)$, and lastly site $\mathrm{A}\left(0.05 \mathrm{ind} \cdot \mathrm{m}^{-2}\right)$.

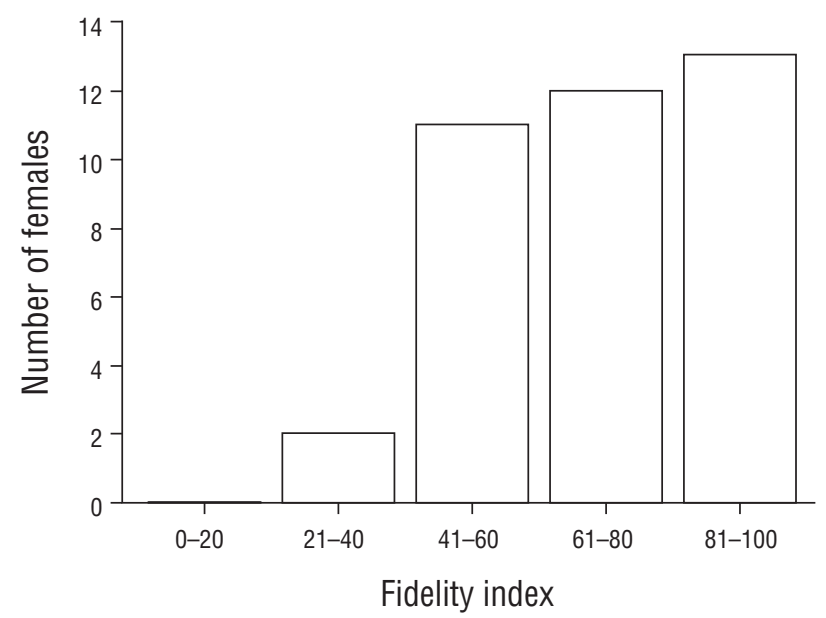

Figure 2. Individual fine-scale site fidelity index for female California sea lions (Zalophus californianus) at Los Islotes rookery, Gulf of California, Mexico.

Figura 2. Índice de fidelidad al sitio individual de hembras de lobo marino de California (Zalophus californianus) en la lobera Los Islotes, golfo de California, México.
En algunas especies, la fidelidad al sitio a escala fina varía dependiendo de la categoría de edad, el éxito reproductivo y la densidad de individuos en las colonias (Cameron et al. 2007, Wolf y Trillmich 2007). En general, los adultos muestran mayor fidelidad al sitio que los jóvenes, debido a que los jóvenes exploran sitios alternativos en la colonia de nacimiento u otras colonias al ser excluidos de las áreas reproductivas (Baker et al. 1995). Para el lobo marino de California, no pudimos analizar la fidelidad al sitio por categorías de edad porque teníamos más datos de hembras en las clases de edad más jóvenes, ya que el estudio de la fidelidad al sitio se inició a partir de 1994, cuando ya habían muerto algunas de las hembras de las primeras cohortes.

El grado de fidelidad al sitio a escala fina se relaciona positivamente con el éxito reproductivo de las hembras o con el número de crías en los territorios en casos como el del lobo marino Antártico (Lunn y Boyd 1991), el lobo marino de Galápagos (Wolf y Trillmich 2007) y la foca de Weddell (Cameron et al. 2007). No obstante, en el presente estudio no se encontró una relación positiva entre el éxito reproductivo y la fidelidad al sitio a escala fina, ni tampoco se encontró un sitio preferido para la crianza; creemos que las tendencias opuestas en el porcentaje de hembras con crías entre años y sitios se deben al azar. Si uno de los sitios fuera mejor para la crianza, el porcentaje de hembras con crías en ese sitio sería mayor en todos los años de estudio.

En cuanto a la densidad de animales en las colonias, Matthiopoulos et al. (2005) mencionaron que las poblaciones que disminuyen su tamaño lentamente o que tienen densidades bajas son más propensas a mostrar altos niveles de fidelidad al sitio y filopatría que aquellas con un incremento de tamaño poblacional rápido o con altas densidades poblacionales. En el presente estudio, no contamos con datos de densidad de animales para cada sitio en todos los años, excepto para 2000, 2002 y 2003 (Young y Gerber 2008), por lo que no pudimos relacionar la densidad poblacional con el índice de fidelidad al sitio a escala fina para todo el periodo de estudio. Sin embargo, al analizar esos 3 años, encontramos que la mayor densidad se presentó en el sitio B $\left(0.20\right.$ ind $\left.\cdot \mathrm{m}^{-2}\right)$, seguido del sitio $\mathrm{C}\left(0.09 \mathrm{ind} \cdot \mathrm{m}^{-2}\right) \mathrm{y}$, por último, el sitio A $\left(0.05\right.$ ind $\left.\cdot \mathrm{m}^{-2}\right)$. El sitio A, que tiene menor densidad, también presentó el mayor índice de fidelidad al sitio a escala fina y la mayor tasa de retorno, tal como lo sugerido por Matthiopoulos et al. (2005).

El índice de fidelidad al sitio a escala fina para el lobo marino de California en Los Islotes fue alto a pesar de que el tamaño de la colonia estaba aumentado rápidamente (Szteren et al. 2006). Esto quizás se deba a que el tamaño de la población durante el periodo de estudio era pequeño (entre 300 y 400 individuos), por lo que había espacio suficiente para los individuos. Actualmente, el tamaño de la población ( 600 individuos) y la densidad (ver subsección Área de estudio) han ido en aumento, por lo que es probable que el índice de fidelidad al sitio a escala fina sea menor. Esta condición puede provocar un menor grado de endogamia y 

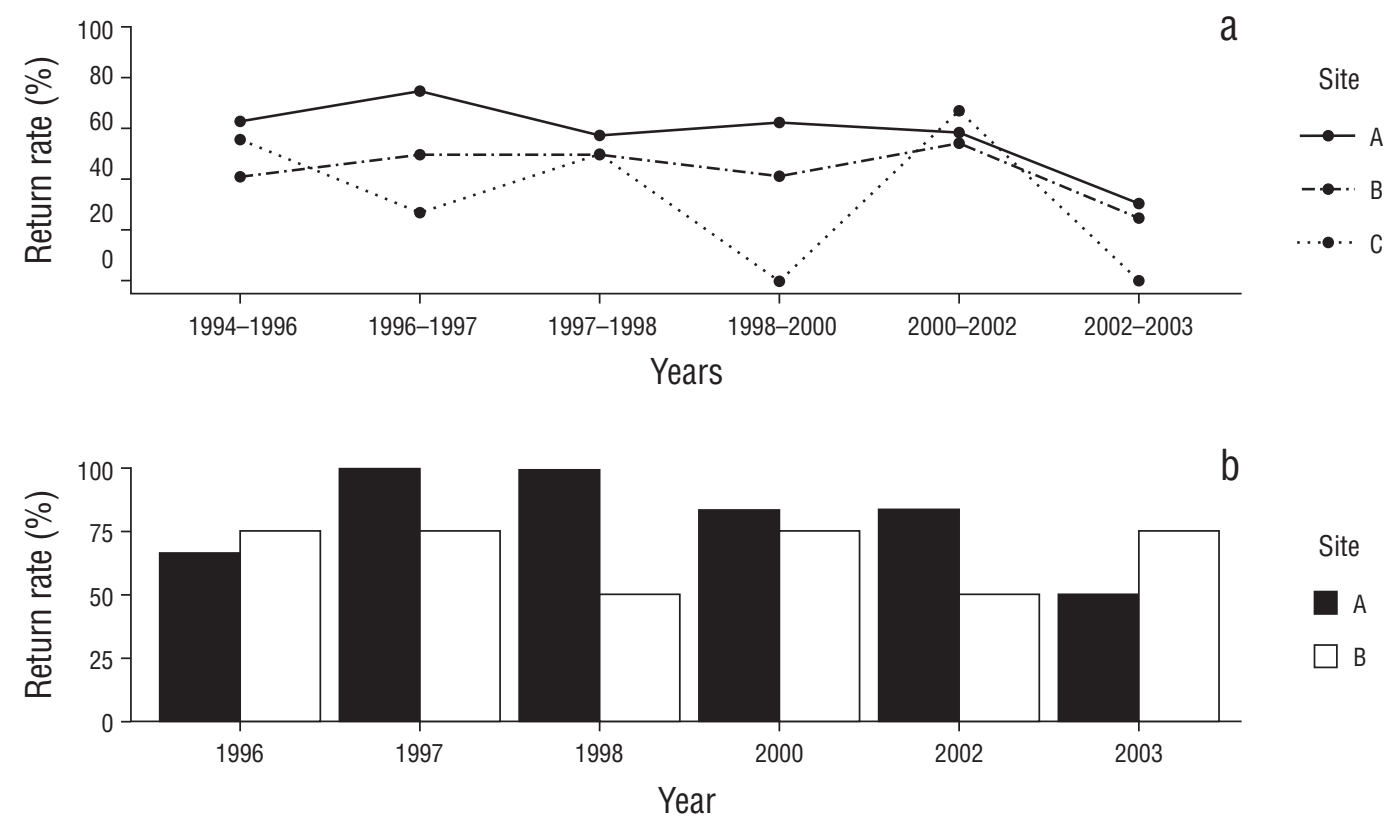

Figure 3. Return rate for female California sea lions (Zalophus californianus) at sites A, B, and C for each year with respect to the previous year (a) and for each year with respect to 1994 (b). Each interval on the $x$-axis shows the number of recaptured animals from the previous year.

Figura 3. Tasa de retorno de hembras lobo marino de California (Zalophus californianus) en los sitios A, B y C para un año con respecto al anterior (a) y para un año con respecto a 1994 (b). Cada intervalo en el eje $x$ muestra el número de animales recapturados del año previo.
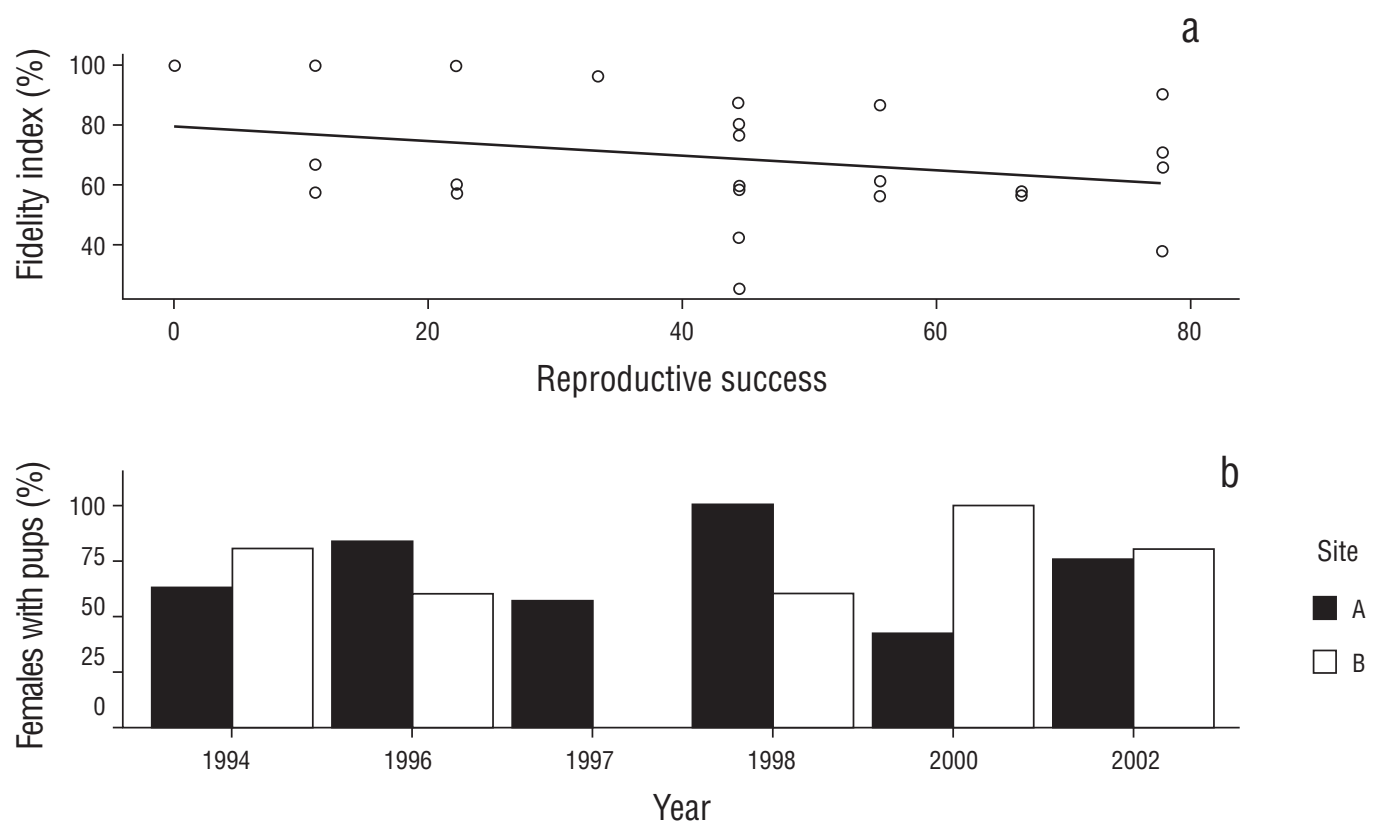

Figure 4. (a) Pearson correlation between individual reproductive success and fine-scale site fidelity index during the sampling years. (b) Reproductive success of females at sites A and B.

Figura 4. (a) Correlación de Pearson entre el éxito reproductivo individual y el índice de fidelidad al sitio durante los años de muestreo. (b) Éxito reproductivo de las hembras en los sitios A y B. 
Rayas-Estrada and Hernández-Camacho: Fine-scale site fidelity in California sea lions

Site A, with the lowest density, showed the highest fine-scale site fidelity index and the highest return rate, as in the finding by Matthiopoulos et al. (2005).

At Los Islotes, the fine-scale site fidelity index for the California sea lion was high despite the rapid increase in the size of the colony (Szteren et al. 2006). This could be due to the fact that the population size during the study period was small (between 300 and 400 individuals), and there was plenty of space available for all individuals. At present, population size ( $\sim 600$ individuals) and density (see Study area above) have been increasing, so it is possible that the finescale site fidelity index is lower. This condition could reduce endogamy and altruism in the colony (Greenwood 1980, Matthiopoulos et al. 2005).

High levels of philopatry and fine-scale site fidelity promote endogamous breeding, resulting in low genetic variability, which in turn, affects the reproductive success of individuals and, eventually, the growth of a population (Chilvers and Wilkinson 2008, Serna-Lagunes and Díaz-Rivera 2011). The California sea lion colony at Los Islotes does not show low genetic variability (GonzálezSuárez et al. 2009), indicating endogamous mating is not taking place there. We believe there are 3 mechanisms preventing endogamy and generational overlap in organisms showing high philopatry and fine-scale site fidelity. The first has to do with the breeding time gap between birth and the first reproduction event, which exceeds the average reproductive life span of the parents (4-5 years) and reduces the probability of parents breeding with their descendants (Clutton-Brock 1989, Hernández-Camacho 2001). California sea lion females reproduce for the first time at 4 or 5 years of age and continue reproducing until they are 25 years old (Hernández-Camacho et al. 2008b, Melin et al. 2012); males reproduce at 8 or 9 years of age and their territorial life time lasts for $4.2 \pm 1.7 \mathrm{yr}$ (Peterson and Bartholomew 1967). Thus, when a female starts to reproduce, her father is no longer reproductively active; however, when a male starts his reproductive life, its mother is still reproductively active, but their reproductive years overlap in only 4 of the 20 years of the reproductive life time of that female. The second mechanism deals with the higher male mortality rates (Hernández-Camacho et al. 2008a), which prevent adult males from breeding with their mothers or sisters. Only $23 \%$ of all males reach adulthood (9 years), whereas $47 \%$ of females reach adulthood (Hernández-Camacho 2001). Therefore, the probability of them mating is low. Finally, the third mechanism has to do with the fact that few adult males have territories inside the colony, which reduces the probability of inbreeding. However, genetic evidence indicates that this mechanism could not be operating here. Using microsatellite markers for pups and territorial males in 2 colonies from the Gulf of California, Flatz et al. (2012) found that territorial males fathered a low percentage of pups born at these sites and suggested that females were impregnated outside the breeding territories. de altruismo en la colonia (Greenwood 1980, Matthiopoulos et al. 2005).

El alto grado de filopatría y fidelidad al sitio a escala fina favorece los apareamientos endogámicos, lo que resulta en baja variabilidad genética, que, a su vez, afecta el éxito reproductivo de los individuos y, eventualmente, el crecimiento de una población (Chilvers y Wilkinson 2008, Serna-Lagunes y Díaz-Rivera 2011). La colonia de lobo marino de California de Los Islotes no presenta variabilidad genética reducida (González-Suárez et al. 2009), lo que sugiere que no hay apareamientos endogámicos. Creemos que esto se debe a que existen 3 mecanismos que previenen la endogamia y el traslape de generaciones en organismos con alto grado de filopatría y fidelidad al sitio a escala fina. El primero es el desfase de reproducción, donde el tiempo entre el nacimiento y la primera reproducción sobrepasan la vida reproductiva promedio de los padres (4-5 años), por lo que la probabilidad de que los padres se apareen con sus descendientes es baja (Clutton-Brock 1989, Hernández-Camacho 2001). En las hembras de lobo marino de California, la reproducción comienza entre los 4 y 5 años y continúa hasta los 25 (Hernández-Camacho et al. 2008b, Melin et al. 2012); en cambio, los machos comienzan a reproducirse a los 8 o 9 años y su vida territorial promedio dura $4.2 \pm 1.7$ años (Peterson y Bartholomew 1967). Por tanto, cuando una hembra inicia su actividad reproductiva, su padre ya no está reproductivamente activo; sin embargo, cuando un macho inicia su actividad reproductiva, su hembra progenitora está activa reproductivamente, pero ellos solo coinciden durante 4 de los 20 años de la vida reproductiva de la hembra. El segundo mecanismo tiene que ver con la mayor tasa de mortalidad en los machos (Hernández-Camacho et al. 2008a), que previene que un macho adulto se aparee con su madre o su hermana. Únicamente el $23 \%$ de todos los machos sobrevive a la etapa adulta ( 9 años), mientras que el $47 \%$ de las hembras sobrevive a la edad adulta (Hernández-Camacho 2001). Por lo tanto, la probabilidad de que se apareen es baja. Finalmente, el tercer mecanismo tiene que ver con que un bajo porcentaje de los machos adultos tiene un territorio dentro de la colonia, lo que reduce la probabilidad de aparearse con una consanguínea. Sin embargo, hay evidencia genética que sugiere que este mecanismo podría no estar operando. Flatz et al. (2012) utilizaron marcadores microsatelitales en crías y machos territoriales en 2 colonias del golfo de California y encontraron que los machos territoriales fueron los padres de un bajo porcentaje de las crías nacidas en esos sitios, por lo que los autores proponen que las hembras fueron preñadas fuera de los territorios reproductivos.

Si los machos territoriales no se aparean con las hembras, entonces debe existir un beneficio al permanecer en los territorios y defenderlos. Una hipótesis es que los machos se benefician indirectamente de la defensa de los territorios al favorecer su adecuación individual a través del incremento de la supervivencia de las crías de las hembras emparentadas, como lo predice la teoría de selección de parentesco 
If territorial males are not mating with females, then they must be obtaining another benefit from staying in the territories and defending them. One hypothesis is that territorial defense favors male fitness by increasing the survival of pups from related females, as predicted by the kin selection theory (Hamilton 1964). For example, territorial Galápagos sea lion males confront sharks that approach their territories; it is believed that this risky behavior is to defend pups (Trillmich 1996), although other authors believe pups indirectly benefit from this behavior (Miller 1974). In the case of the California sea lion, territorial males could play a role in preventing other males from altering the tranquility of the colony where females are giving birth and nursing their pups.

Though in this study we did not analyze fine-scale site fidelity for males because of the small sample size, of the 96 males we branded only 29 were resighted when we started recording the reproductive status and geographic location of branded individuals in the colony. During the 9-year study period (1994-2003), only 3 males from the 1983 and 1984 cohorts were sighted in 6 to 9 consecutive seasons. The fine-scale site fidelity indices for these 3 individuals were $93 \%, 23 \%$, and $52 \%$. The possibility exists that the males that were not observed in one breeding season could have been present in another colony. Nonetheless, we believe this number was low because during cruises carried out in the Gulf of California from the first branding year to 2003, only one 15-year old female was recorded at San Esteban Island (508 km north of Los Islotes) in 1997, one young female at Granito Island (638 km north of Los Islotes) in 1984, and one young male at San Pedro Mártir (465 km north of Los Islotes) in 1985. These 3 individuals were resighted at Los Islotes in later years (Hernández-Camacho 2001).

Genetic studies are needed to determine the degree of kinship between individuals from different age classes in this colony. Furthermore, evaluating territorial behavior during the breeding season will allow us to further understand the polygonous mating system in this pinniped species.

\section{ACKNOWLedgments}

We are infinitely grateful for the funding provided by the National Commission for the Knowledge and Use of Biodiversity (Mexico, H081), the National Polytechnic Institute (Administration System for Programs and Research Projects 20030304), and the Division of Postgraduate Studies and Research of the National Polytechnic Institute (968013). This study was carried out under the following research permits granted by the Ministry of Environment and Natural Resources (Mexico): no. 240996-213-03, DOO 750.-4172/97, DOO 750.-4443/98, NUM / SGPA / DGVS 04311, 04160, 05325, and 03269. We thank Dr. Martha Patricia Rosas for statistical support and programming advice for the data analysis. We report no conflict of interest.

English translation by Claudia Michel-Villalobos.
(Hamilton 1964). Por ejemplo, los machos territoriales de lobo marino de Galápagos confrontan a los tiburones que se acercan a los territorios; se cree que este comportamiento arriesgado es realizado para defender a las crías (Trillmich 1996), aunque otros autores opinan que las crías se benefician indirectamente de este comportamiento (Miller 1974). En el caso del lobo marino de California, es posible que el papel de los machos territoriales sea prevenir que otros machos alteren la tranquilidad de la colonia donde las hembras están dando a luz y amamantando a las crías.

Aunque en este estudio no analizamos la fidelidad al sitio a escala fina de los machos debido al pequeño tamaño de su muestra, de los 96 machos que marcamos, únicamente re-avistamos 29 individuos cuando empezamos a registrar el estado reproductivo y la ubicación de los animales marcados dentro de la colonia. En los 9 años (1994-2003) de estudio, solo 3 machos de las cohortes 1983 y 1984 fueron vistos entre 6 y 9 temporadas consecutivas. El índice de fidelidad al sitio a escala fina para estos 3 individuos fue de $93 \%, 23 \%$ y $52 \%$. Es posible que los machos que no fueron vistos durante una temporada de reproducción hayan estado en otras colonias. No obstante, creemos que este número fue bajo debido a que durante cruceros por el golfo de California realizados desde el primer año de marcaje hasta 2003, únicamente se observaron una hembra de 15 años en isla San Esteban (508 km al norte de Los Islotes) en 1997, una hembra joven en isla Granito $(638 \mathrm{~km}$ al norte de Los Islotes) en 1984 y un macho joven en San Pedro Mártir (465 km al norte de Los Islotes) en 1985. Los 3 individuos fueron re-avistados en Los Islotes en años posteriores (Hernández-Camacho 2001).

Es necesario realizar estudios de genética para determinar el grado de parentesco entre los individuos de las distintas clases de edad en esta colonia. Además, evaluar el comportamiento territorial a lo largo de la temporada de reproducción nos permitirá tener un mejor entendimiento de cómo opera el sistema reproductivo poligínico en este pinípedo.

\section{Agradecimientos}

Agradecemos infinitamente el financiamiento proporcionado por la Comisión Nacional para el Conocimiento y Uso de la Biodiversidad (México, H081), el Instituto Politécnico Nacional (Sistema de Administración de Programas y Proyectos de Investigación 20030304), y la División de Estudios de Posgrado e Investigación del Instituto Politécnico Nacional (968013). Este estudio se realizó bajo los siguientes permisos de investigación otorgados por la Secretaría de Medio Ambiente y Recursos Naturales (México): no. 240996213-03, DOO 750.-4172/97, DOO 750.-4443/98, NUM/ SGPA/DGVS 04311, 04160, 05325 y 03269. Agradecemos a la Dra. Martha Patricia Rosas apoyo estadístico y asesorías de programación para el análisis de los datos. Reportamos que no existe conflicto de intereses. 
Rayas-Estrada and Hernández-Camacho: Fine-scale site fidelity in California sea lions

\section{REFERENCES}

Acevedo JA, Aguayo-Lobo A, Pastene LA. 2006. Filopatría de la ballena jorobada (Megaptera novaeangliae Borowski, 1781), al área de alimentación del estrecho de Magallanes $=$ Site fidelity of humpback whales (Megaptera novaeangliae Borowski, 1781) to the Magellan Strait feeding ground. Rev. Biol. Mar. Oceanogr. 41(1): 11-19. http://dx.doi.org/10.4067/S0718-19572006000100004

Amos W, Harwood J. 1998. Factors affecting levels of genetic diversity in natural populations. Phil. Trans. R. Soc. Lond. B 353(1366): 177-186. http://dx.doi.org/10.1098/rstb.1998.0200

Aurioles D, Sinsel F. 1988. Mortality of California Sea Lion Pups at Los Islotes, Baja California Sur, Mexico. J. Mammal. 69(1): 180-183. https://doi.org/10.2307/1381771

Baker JD, Antonelis GA, Fowler CW, York AE. 1995. Natal site fidelity in northern fur seals, Callorhinus ursinus. Anim. Behav. 50(1): 237-247. https://doi.org/10.1006/anbe.1995.0236

Cameron MF, Siniff DB, Proffitt KM, Garrott RA. 2007. Site fidelity of Weddell seals: the effects of sex and age. Antarct. Sci. 19(2): 149-155. https://doi.org/10.1017/S0954102007000223

Campbell RA, Gales NJ, Lento GM, Baker CS. 2007. Islands in the sea: extreme female natal site fidelity in the Australian sea lion, Neophoca cinerea. Biol. lett. 4(1): 139-142. https://doi.org/10.1098/rsbl.2007.0487

Cassini MH. 2000. A model on female breeding dispersion and the reproductive systems of pinnipeds. Behav. Process. 51(1-3): 93-99. https://doi.org/10.1016/s0376-6357(00)00121-2

Chesser RK. 1998. Relativity of behavioral interactions in socially structured populations. J. Mammal. 79(3): 713-724. https://doi.org/10.2307/1383082

Chilvers BL, Wilkinson IS. 2008. Philopatry and site fidelity of New Zealand sea lions (Phocarctos hookeri). Wildl. Res. 35(5): 463-470. https://doi.org/10.1071/wr07053

Clutton-Brock TH. 1989. Female transfer and inbreeding avoidance in social mammals. Nature 337: 70-72. https://doi.org/10.1038/337070a0

DeLong RL, Melin SR, Laake JL, Morris P, Orr AJ, Harris JD. 2017. Age- and sex- specific survival of California sea lions (Zalophus californianus) at San Miguel Island, California. Mar. Mammal Sci. 33(4): 1097-1125. https://doi.org/10.1111/mms.12427

Elorriaga-Verplancken FR, Sandoval-Sierra J, Paniagua-Mendoza A, Robles-Hernández R. 2018. Seasonality and potential foraging grounds of migratory California sea lions from La Paz Bay, Southern Gulf of California, Mexico. Aquat. Mamm. 44(1): 56-61. https://doi.org/10.1578/AM.44.1.2018.56

Flatz R, González-Suárez M, Young JK, Hernández-Camacho CJ, Immel AJ, Gerber LR. 2012. Weak polygyny in California sea lions and the potential for alternative mating tactics. PLOS ONE 7(3): e33654.

https://doi.org/10.1371/journal.pone.0033654

García-Aguilar MC, Aurioles-Gamboa D. 2003. Cuidado materno en el lobo marino de California de Los Islotes, Golfo de California, México = Maternal care in the California sea lion at Los Islotes, Gulf of California, Mexico. Cienc. Mar. 29(4B): 573-583. https://doi.org/10.7773/cm.v29i42.199

González-Forero MG. 1998. ¿Dispersión o Filopatría?, Análisis de Sus Causas y Consecuencias En La Población de Milanos
Negros de Doñana [Dispersion or Philopatry? Analysis of its Causes and Consequences in the Population of Black Doves of Doñana] [dissertation]. [Spain]: Universidad de Sevilla; 185pp.

González-Suárez M, Flatz R, Aurioles-Gamboa D, Hedrick PW, Gerber LR. 2009. Isolation by distance among California sea lion populations in Mexico: redefining management stocks. Mol. Ecol. 18(6): 1088-1099.

https://doi.org/10.1111/j.1365-294X.2009.04093.x

Greenwood PJ. 1980. Mating systems, philopatry and dispersal in birds and mammals. Anim. Behav. 28(4): 1140-1162. https://doi.org/10.1016/s0003-3472(80)80103-5

Hamilton WD. 1964. The genetical evolution of social behaviour. II. J. Theor. Biol. 7(1): 17-52. https://doi.org/10.1016/0022-5193(64)90039-6

Hernández-Camacho CJ. 2001. Tabla de vida del lobo marino de California Zalophus californianus californianus en la lobera Los Islotes, B.C.S., México [Life history of the California sea lion, Zalophus californianus californianus, In Los Islotes lobera, B.C.S., Mexico] [MSc thesis]. [Mexico (La Paz, Baja California)]: Centro Interdisciplinario de Ciencias Marinas del Instituto Politécnico Nacional; 75pp.

Hernández-Camacho CJ, Aurioles-Gamboa D, Laake J, Gerber LR. 2008a. Survival rates of the California sea lion, Zalophus californianus, in Mexico. J. Mammal. 89(4): 1059-1066. https://doi.org/10.1644/07-MAMM-A-404.1

Hernández-Camacho CJ, Aurioles-Gamboa D, Gerber LR. 2008 b. Age-specific birth rates of California sea lions (Zalophus californianus) in the Gulf of California, Mexico. Mar. Mammal Sci. 24(3): 664-676. https://doi.org/10.1111/j.1748-7692.2008.00199.x

Hoffman JI, Forcada J. 2012. Extreme natal philopatry in female Antarctic fur seals (Arctocephalus gazella). Mamm. Biol. 77(1): 71-73.

https://doi.org/10.1016/j.mambio.2011.09.002

King JE. 1983. Seals of the world. 2nd ed. Ithaca (NY): Cornell University Press.

Labrada-Martagón V, Aurioles-Gamboa D, Martínez-Díaz SF. 2005. Natural and human disturbance in a rookery of the California sea lion (Zalophus californianus californianus) in the Gulf of California, Mexico. Lat. Am. J. Aquat. Mamm. 4(2): $175-185$. https://doi.org/10.5597/lajam00080

Lunn NJ, Boyd IL. 1991. Pupping-site fidelity of Antarctic fur seals at Bird Island, South Georgia. J. Mammal. 72(1): 202-206. https://doi.org/10.2307/1381999

Matthiopoulos J, Harwood J, Thomas L. 2005. Metapopulation consequences of site fidelity for colonially breeding mammals and birds. J. Anim. Ecol. 74(4): 716-727. https://doi.org/10.1111/j.1365-2656.2005.00970.x

Melin SR, DeLong RL, Thomason JR, Van Blaricom GR. 2000. Attendance patterns of California sea lion (Zalophus californianus) females and pups during the non-breeding season at San Miguel Island. Mar. Mammal Sci. 16(1): 169-185. https://doi.org/10.1111/j.1748-7692.2000.tb00911.x

Melin SR, Laake JL, DeLong RL, Siniff DB. 2012. Age-specific recruitment and natality of California sea lions at San Miguel Island, California. Mar. Mammal Sci. 28(4): 751-776. https://doi.org/10.1111/j.1748-7692.2011.00538.x

Miller EH. 1974. A paternal role in Galapagos sea lions? Evolution 28(3): 473-476. https://doi.org/10.2307/2407168

Peterson RS, Bartholomew GA. 1967. The natural history and behavior of the California sea lion. Am. Soc. Mammal. Spec. Pub. no.1, 79 pp.

https://doi.org/10.5962/bhl.title.39535 
Pomeroy PP, Twiss SD, Redman P. 2000. Philopatry, site fidelity and local kin associations within grey seal breeding colonies. Ethology 106(10): 899-919. https://doi.org/10.1046/j.1439-0310.2000.00610.x

R Core Team. 2018. R: a language and environment for statistical computing. Vienna: R Foundation for Statistical Computing; [accessed 23 Jan 2018]. https://www.R-project.org/

Schramm Y, Mesnick SL, de la Rosa J, Palacios DM, Lowry MS, Aurioles-Gamboa D, Snell HM, Escorza-Treviño S. 2009. Phylogeography of California and Galápagos sea lions and population structure within the California sea lion. Mar. Biol. 156(7): 1375-1387. https://doi.org/10.1007/s00227-009-1178-1

Serna-Lagunes R, Díaz-Rivera P. 2011. Variación genética y conservación de una población de Crocodylus moreletii en cautiverio [Genetic variation and conservation of a population of Crocodylus moreletii in captivity]. Acta Zool. Mex. 27(3): $547-563$. https://doi.org/10.21829/azm.2011.273773

Szteren D, Aurioles-Gamboa D, Gerber LR. 2006. Population status and trends of the California sea lion (Zalophus californianus californianus) in the Gulf of California, Mexico. In: Trites AW, Atkinson SK, De Master DP, Fritz LW, Gelatt TS, Rea LD, Wayne KM (eds.), Sea Lions of the World. 22nd Lowell
Wakefield Symposium [September 2004]; Anchorage (Alaska). Fairbanks (AK): Alaska Sea Grant College Program [University of Alaska]; 664 pp. [AK-SG-06-01] https://doi.org/10.4027/slw.2006.25

Trillmich F. 1996. Parental investment in pinnipeds. Adv. Study Behav. 25: 533-577. https://doi.org/10.1016/s0065-3454(08)60342-3

Wolf JBW, Kauermann G, Trillmich F. 2005. Males in the shade: habitat use and sexual segregation in the Galápagos sea lion (Zalophus californianus wollebaeki). Behav. Ecol. Sociobiol. 59(2): 293-302. https://doi.org/10.1007/s00265-005-0042-7

Wolf JBW, Trillmich F. 2007. Beyond habitat requirements: individual fine-scale site fidelity in a colony of the Galapagos sea lion (Zalophus wollebaeki) creates conditions for social structuring. Oecologia 152(3): 553-567. https://doi.org/10.1007/s00442-007-0665-7

Young JK, Gerber LR. 2008. The influence of social composition on reproductive behavior of territorial male California sea lions. Aquat. Mamm. 34(1): 102-108. https://doi.org/10.1578/AM.34.1.2008.102

Received June 2019, accepted November 2019. 